\title{
Association between insulin-like growth factor I (IGF-I) microsatellite polymorphisms and important economic traits in pigs ${ }^{1}$
}

\author{
Danielle Assis de Faria², Jane de Oliveira Peixoto², Paulo Sávio Lopes², Samuel Rezende \\ Paiva $^{3}$, Priscila Vendramini Silva ${ }^{2}$, Simone Eliza Facioni Guimarães ${ }^{2}$ \\ 1 Pesquisa financiada pela CAPES e FAPEMIG. \\ 2 Departamento de Zootecnia, Universidade Federal de Viçosa, CEP: 36570-000, Viçosa, MG, Brasil. \\ ${ }^{3}$ Laboratório Genética Animal, Embrapa Recursos Genéticos e Biotecnologia, CEP: 70770-900, Brasília, DF, Brasil.
}

\begin{abstract}
This study investigated the association between IGF-I microsatellite marker in an $\mathrm{F}_{2}$ population $(\mathrm{N}=459)$ generated by mating of native boars to Brazilian commercial sows with performance, carcass cut, and meat quality traits Association analyses were carried out using a statistical model that included genotype, sex, and group as fixed effects and sire as random effect. The IGF-I genotypes were significantly associated with different quantitative traits and these results corroborate with previous QTL analyses obtained for this chromosome region in swine. Additive and dominance effects, as well as a genotype-sex interaction, were estimated and discussed in the text. According to the results obtained, this marker is suitable for QTL search in the genotyped population.
\end{abstract}

Key Words: divergent cross, microsatellite marker, quantitative traits, sex $\times$ genotype interaction, swine

\section{Associação entre polimorfismos no marcador microssatélite do gene do fator de crescimento semelhante à insulina I (IGF-I) com características de interesse econômico em suínos}

\begin{abstract}
RESUMO - Investigou-se neste trabalho a associação entre o marcador microssatélite IGF-I em uma população F2 $(\mathrm{N}=459)$ gerada pelo acasalamento entre suínos nativos brasileiros e fêmeas comerciais com características de desempenho, cortes de carcaça e qualidade da carne. A análise de associação foi feita por meio de um modelo que incluiu genótipo, sexo e grupo como efeitos fixos e pais como efeito aleatório. Os genótipos do IGF-I apresentaram associação significativa com nove características quantitativas, resultados que corroboram análises prévias de QTL obtidas para essa região cromossômica em suínos. Efeitos aditivos de dominância, assim como a interação genótipo $\times$ sexo, foram estimados e estão descritos neste trabalho. De acordo com os resultados obtidos, este marcador será útil nas análises de QTL na população analisada.
\end{abstract}

Palavras-chave: características quantitativas, cruzamentos divergentes, interação sexo e genótipo, marcadores microssatélites, suínos

\section{Introduction}

Animal breeding and selection change the genotype composition of individuals over various generations, with a consequent variation in allele frequency in order to obtain animals with phenotypes demanded by producers and consumers. The main purpose of pig breeding is to obtain fast growing animals with high lean meat yield and low fat deposition, in addition to improved meat quality traits. One option to reach these goals is to identify gene loci related to each one of these traits and to incorporate this information into traditional breeding methods. Marker-derived data should be included in traditional genetic improvement programs. The insulin-like growth factor I (IGF-I) gene is considered as a candidate gene due to its importance in growth and body composition of animals (Horvat \& Medrano, 1995; Yu et al. 1995). The genomic DNA region encoding the IGF-I gene in pigs was cloned and sequenced, and it is located on chromosome 5 (SSC 5) (Weller et al., 1993). The IGF-I gene presents a microsatellite in the 5 ' region. CasasCarrillo et al. (1997) identified a quantitative trait locus (QTL) for the mean daily weight gain in pigs, with the IGF-I locus being related to this trait. De Koning et al. (2001) found a suggestive QTL for life growth (LGR) and ultrasound backfat thickness (BFT) in the same chromosome interval (which involves the S0005 and IGF-I - at $80 \mathrm{cM}$ markers), 
however the QTL affecting BFT is paternally expressed, whereas maternal expression was inferred for the QTL affecting LGR. For backfat traits, QTLs on SSC 5 for lumbar backfat, average backfat, and last rib backfat were identified, showing that some candidate gene(s) for this traits are located close to IGF-I loci (Malek et al. 2001a). The objective of the present study was to genotype a parental, F1 and F2 population generated by the divergent crossing between native Piau boars and commercial sows for the microsatellite flanking the 5' region of the IGF-I gene. In addition, the alleles were associated with traits of economical interest to pig breeding.

\section{Material and Methods}

The experimental F2 population, the phenotypes, and the DNA extraction procedures were fully described by Band etal.(2005a,b), Faria etal.(2006), and Peixoto etal.(2006).

The primer pair used to amplify the IGF-I microsatellite (GenBank X64400 and BI402878) was fluorescence labeled (6' FAM) and had the following sequence: A - 5' GCTTGGATGGACCATGTTG $3^{\prime}$ and B - 5' CATATTTTTCTGCTTACTTGAACCT 3'. The specific DNA fragment was amplified through polymerase chain reaction (PCR) in an Eppendorf Mastercycler Gradient thermocycler. The reaction mixture contained $4.0 \mathrm{pmol}$ of each primer, $0.2 \mathrm{mM}$ of each dNTP, $1.0 \mathrm{mM} \mathrm{MgCl}_{2}, 50 \mathrm{mM}$ Tris-KCl, $1.0 \mathrm{U}$ Taq DNA polymerase, and $25 \mathrm{ng}$ genomic DNA in a final volume of $20.0 \mu \mathrm{L}$. PCR amplification consisted of an initial denaturation step at $94^{\circ} \mathrm{C}$ for $5 \mathrm{~min}$ and 35 cycles of strand denaturation at $94^{\circ} \mathrm{C}$ for $1 \mathrm{~min}$, primer annealing at $58^{\circ} \mathrm{C}$ for $1 \mathrm{~min}$, and fragment extension at $72^{\circ} \mathrm{C}$ for $1 \mathrm{~min}$, followed by a final extension step at $72^{\circ} \mathrm{C}$ for $30 \mathrm{~min}$.

Next, $5 \mu \mathrm{L}$ of the reaction was applied on a $2 \%$ agarose gel stained with ethidium bromide for visualization of the amplification products. The samples were then submitted to capillary electrophoresis in an ABI Prism 310 automatic sequencer at the Laboratory of Animal Biotechnology (LABTEC), Department of Animal Science, Viçosa Federal University, for fragment scoring and detection of polymorphisms. The scores of the amplified fragments were obtained using the GenScan software.

For statistical analysis, the microsatellite was considered as a single marker. The database consisted of two basic files: one containing phenotypic measures of all traits and the other containing the marker genotypes. In the $\mathrm{F}_{2}$ generation, the alleles were coded according to origin as 1 , 2 or 3 , where 1 corresponds to the commercial homozygous genotype (CC), 2 corresponds to heterozygous animals (Commercial x Piau, CP), and 3 corresponds to homozygous Piau animals (PP).

The statistical analysis of the association between genotypes and traits was performed with PROC GLM module of the SAS program (1998), based on the model below: $\mathrm{y}_{\mathrm{ijklm}}=\mathrm{a}+\mathrm{G}_{\mathrm{i}}+\mathrm{S}_{\mathrm{j}}+\mathrm{GS}_{\mathrm{ij}}+\mathrm{L}_{\mathrm{k}}+\mathrm{p}_{1}+\left(C_{i j k m}-\bar{C}\right) b+\mathrm{e}_{\mathrm{ijklm}}$ where $\mathrm{y}_{\mathrm{ijklm}}=$ trait observed in animal $\mathrm{m}$ of genotype $\mathrm{i}, \operatorname{sex} \mathrm{j}$, batch $\mathrm{k}$, and father $\mathrm{l} ; \mathrm{a}=$ overall mean; $\mathrm{G}_{\mathrm{i}}=$ fixed effect of genotype $i(i=1,2,3) ; S_{j}=$ fixed effect of $\operatorname{sex~} j, j=1,2$ ( 1 = castrated male, $2=$ female $) ; \mathrm{GS}_{\mathrm{ij}}=$ interaction between genotype $\mathrm{i}$ and $\operatorname{sex} \mathrm{j} ; \mathrm{L}_{\mathrm{k}}=$ fixed effect of birth season $\mathrm{k}$ $(\mathrm{k}=1,2,3,4,5) ; \mathrm{p}_{1}=$ random effect of father $1 ; \mathrm{b}=$ linear regression coefficient of trait $\mathrm{y}_{\mathrm{ijk} k \mathrm{~m}}$ in relation to the covariate; $\mathrm{C}_{\mathrm{ijklm}}=$ covariate value observed in animal $\mathrm{m}$ from genotype $\mathrm{i}$, sex $\mathrm{j}$, batch $\mathrm{k}$, and father $\mathrm{l} ; \bar{C}=$ mean covariate value; and $\mathrm{e}_{\mathrm{ijklm}}=$ random error associated with each observation.

The following covariates were used: litter size at birth for birth weight; litter size at weaning for traits weight at 21 , $42,63,77$, and 105 days of age and slaughter weight; weight at 77 days for traits feed intake, average daily gain, and feedgain ratio; carcass weight for all carcass traits; cooled right half carcass weight for carcass cut traits; age at slaughter for meat quality traits. No covariate was used for the total, left, and right number of teats.

The covariances between genetic and environmental (permanent and temporary) effects, as well as between environmental effects from different animals, were considered as zero. The difference between genotypes was tested by analysis of variance (F test) at $10 \%$ of significance level. Genotype means were compared through the t-test. When the genotype-sex interaction was significant, genotype means were compared within each sex through the t-test.

Dominance effects were evaluated through linear contrasts between genotype means. The t-test was applied to determine the significance of the dominance effect.

In a parallel analysis using the genotypes obtained for the three generations (parental, $\mathrm{F}_{1}$, and $\mathrm{F}_{2}$ ), the allele frequencies, heterozygosity, and the polymorphic information content (PIC) of the locus were estimated by means of the Cervus program (Marshall et al., 1998).

\section{Results and Discussion}

PCR of the IGF-I microsatellite generated specific and polymorphic bands. It was genotyped the IGF-I locus in the 18 commercial sows and 2 native Brazilian boars which made up the parental generation, the observed heterozygosity 
(Ho) was 0.70 , the expected heterozygosity (He) was 0.688 , and the polymorphic information content (PIC) was 0.640 . In the $\mathrm{F}_{1}$ generation, 59 animals were genotyped, and 57 of them were heterozygous. Thus, Ho for this generation was 0.966 and $\mathrm{PIC}$ at this locus was 0.652 . In the $\mathrm{F}_{2}$ generation, 459 animals were genotyped and 441 of them were heterozygous, with Ho of 0.961 and PIC of 0.627 . The paternity exclusion power at this locus was 0.25 when none of the parents was known (PE1) and 0.42 when one of the parents was known (PE2).

Among the 459 animals genotyped in the $\mathrm{F}_{2}$ population, the genotype frequency was $17.4 \%$ (80) for genotype CC, $49.3 \%$ (226) for genotype PC, and 33.3\% (153) for genotype PP (Table 1). The allele frequencies were $42 \%$ for allele $\mathrm{C}$ and $58 \%$ for allele P. A higher frequency of the heterozygous genotype was observed in the $\mathrm{F}_{2}$ generation due to the type of crossing in the $\mathrm{F}_{1}$ and parental generation.

The IGF-I microsatellite locus was highly polymorphic in this population. Seven alleles for this microsatellite were detected in the parental generation (Table 1). Genotyping of F1 animals revealed four of these alleles segregating in this generation; the same alleles were also segregating in the $\mathrm{F}_{2}$ generation. Although the heterozygosity at this locus was high in the $\mathrm{F}_{2}$ generation $(\mathrm{Ho}=0.961)$, some alleles presented a higher frequency (e.g., allele $200 \mathrm{bp}$ ), whereas others showed a low frequency in the population studied (e.g., allele 204). Lee et al. (2003) found heterozygosity values of 0.91 in a crossing between Meishan and Pietran, and 1.00 in a mating between Wild Boar and Meishan. This shows that the heterozigozity values found for this locus is similar in different crossings, indicating that this marker is polymorphic in the population analyzed in the present study and in other populations as well.

The genotypes showed significant association with different traits analyzed in the $\mathrm{F}_{2}$ generation (Table 2). There was a significant effect of the genotypes on liver weight (LIVER), total boston shoulder weight (TBSW), skinless and fatless boston shoulder weight (BSW), sirloin weight (SLW), cooking loss (CL), and on meat color traits (redness $-\mathrm{A}$, yellowness $-\mathrm{B}$, hue angle $-\mathrm{h}$, and chroma - c).

Analysis revealed a higher TBSW mean $(\mathrm{P}<0.05)$ for $\mathrm{PP}$ genotype when compared to the $\mathrm{CC}$ genotype. Higher mean values $(\mathrm{P}<0.05)$ for $\mathrm{B}, \mathrm{h}$, and $\mathrm{c}$, in addition to a lower mean $(\mathrm{P}<0.05)$ for $\mathrm{CL}$, were observed for $\mathrm{CP}$ genotype when compared to $\mathrm{PP}$ or $\mathrm{CC}$ genotypes (Table 2).

It is known that the IGF-I microsatellite is located in a non-coding region of the gene, and one hypothesis to explain its association with quantitative traits would be that the marker, which is located at the 5' region of the gene close to the promoter region (SSC5q23), is in linkage disequilibrium with the gene. According to US Pig Gene Mapping Coordenation Program (http://www.animalgenome.org/pigs), the position of this marker is $118,7 \mathrm{cM}$ on SSC5. Any effect or association found here can be extended to the gene. Since the IGF-I coding region was sequenced (data not shown) and no polymorphism was found in the parental generation, this marker might be linked to some other loci in the same chromosome region (SSC5) or to a regulatory site close to the IGF-I promoter region, which is responsible for the effects here described.

The results obtained for traits total boston shoulder weight (TBSW) and skinless and fatless boston shoulder weight (BSW), for which animals carrying the $\mathrm{P}$ allele presented the best results (Table 2) were not expected, since commercial animals were selected for better performance and higher amount of lean meat, while the native Piau breed is known for its smaller carcass with high fat yield. The Piau breed had been used to provide not only meat but also fat to local communities, and nowadays only a few specimens survive on small rural properties, but this breed is well adapted to precarious management conditions and due to their robustness, they require little nutritional and sanitary care (Carmo et al., 2005).

Table 1 - Number of heterozygotes (Het), homozygotes (Hom), and allele frequencies of the microsatellite marker IGF-I alleles in Parental, $\mathrm{F}_{1}$, and $\mathrm{F}_{2}$ generations

\begin{tabular}{|c|c|c|c|c|c|c|c|c|c|}
\hline \multirow[t]{2}{*}{ Alleles (bp) } & \multicolumn{3}{|c|}{ Parental } & \multicolumn{3}{|c|}{$\mathrm{F}_{1}$ generation } & \multicolumn{3}{|c|}{$\mathrm{F}_{2}$ generation } \\
\hline & Het & Hom & Frequency & Het & Hom & Frequency & Het & Hom & Frequency \\
\hline 194 & 1 & 0 & 0.025 & 0 & 0 & 0 & 0 & 0 & 0 \\
\hline 198 & 3 & 0 & 0.075 & 34 & 0 & 0.290 & 161 & 2 & 0.180 \\
\hline 200 & 3 & 0 & 0.075 & 24 & 0 & 0.200 & 368 & 4 & 0.496 \\
\hline 202 & 9 & 6 & 0.525 & 43 & 2 & 0.390 & 277 & 12 & 0.330 \\
\hline 204 & 4 & 0 & 0.100 & 13 & 0 & 0.120 & 76 & 0 & 0.09 \\
\hline 206 & 7 & 0 & 0.175 & 0 & 0 & 0 & 0 & 0 & 0 \\
\hline 208 & 1 & 0 & 0.025 & 0 & 0 & 0 & 0 & 0 & 0 \\
\hline
\end{tabular}


The IGF-I gene plays an important role in the growth and body composition of animals (Yu et al., 1995), with this hormone controlling the lean muscle tissue. Pursel et al. (2000) observed favorable changes in carcass traits with an increase in the expression of IGF-I. Te Pas et al. (2003) reported significant positive associations between blood plasma IGF-I concentration and growth rate in lines selected for lower backfat thickness. Suzuki et al. (2004) studied Duroc animals and also observed positive correlations between serum IGF-I concentration, performance traits and intramuscular fat, suggesting that animals can be early selected for these traits.

In terms of meat quality, the color parameters are very important, since the color of the fresh meat seems to ultimately influence the consumer purchasing decision. The results showed that the homozygous commercial genotype (CC) could be selected to obtain meat with higher redness (A) (Table 2). On the other hand, in the case of the saturation index (c) which indicates a lower intramuscular fat content, the heterozygous genotype is recommended, since it showed a lower intramuscular fat content, i.e., more lean meat. In addition, the heterozygous genotype presented lower cooking losses (CL) (Table 2). Malek et al. (2001b), analyzing a Berkshire $\mathrm{x}$ Yorkshire $\mathrm{F} 2$ population, identified a QTL on SSC5 for meat color at $113 \mathrm{cM}$, considering that the only marker used in the present study is at $118 \mathrm{cM}$, it is believed that it was detected the effects of this meat color QTL.

There was a significant effect of genotype-sex interaction on performance, internal organs, meat quality, and carcass cut traits (Table 3 ). The results were correlated with the physiology of the IGF-I gene, which is one of the hormones that regulates the animal's growth rate. Genotype means among males and females had a significant effect on different weight parameters and on the average daily gain (ADG). Despite the fact that De Koning, et al. (2001) did not measure the genotype-sex interaction, the results here presented corroborate theirs, since these authors found QTL for backfat and growth traits in the region of $107-113 \mathrm{cM}$ in the SSC5.

Table 2 - Number of observations (N), trait means (Mean), and standard deviations (sd) obtained for IGF-I genotypes for significant performance, carcass, carcass cut, and meat quality traits in $\mathrm{F}_{2}$ animals

\begin{tabular}{|c|c|c|c|c|c|c|c|}
\hline \multirow[t]{2}{*}{ Trait ${ }^{1}$} & \multirow[t]{2}{*}{$\mathrm{F}^{2}$} & \multicolumn{2}{|c|}{ CC genotype } & \multicolumn{2}{|c|}{ CP genotype } & \multicolumn{2}{|c|}{ PP genotype } \\
\hline & & $\mathrm{N}$ & $\operatorname{Mean}^{3} \pm \mathrm{sd}$ & $\mathrm{N}$ & Mean $^{3} \pm \mathrm{sd}$ & $\mathrm{N}$ & Mean $^{3} \pm \mathrm{sd}$ \\
\hline LIVER (kg) & 0.07 & 69 & $1.28 \mathrm{a} \pm 0.13$ & 188 & $1.25 \mathrm{a} \pm 0.14$ & 121 & $1.26 \mathrm{a} \pm 0.41$ \\
\hline TBSW (kg) & 0.01 & 69 & $2.25 \mathrm{a} \pm 0.25$ & 190 & $2.34 b \pm 0.35$ & 123 & $2.35 b \pm 1.31$ \\
\hline BSW (kg) & $<0.01$ & 68 & $1.59 \mathrm{a} \pm 0.01$ & 189 & $1.69 b \pm 0.01$ & 123 & $1.69 b \pm 0.01$ \\
\hline SLW (kg) & $<0.01$ & 68 & $0.22 \mathrm{ab} \pm 0.01$ & 174 & $0.22 \mathrm{a} \pm 0.01$ & 121 & $0.21 b \pm 0.01$ \\
\hline A & 0.05 & 61 & $0.85 \mathrm{a} \pm 0.04$ & 180 & $0.62 b \pm 0.04$ & 108 & $0.72 \mathrm{ab} \pm 0.21$ \\
\hline B & 0.02 & 61 & $6.56 \mathrm{ab} \pm 0.01$ & 180 & $6.69 a \pm 0.01$ & 112 & $6.53 b \pm 0.04$ \\
\hline CL (\%) & 0.09 & 66 & $32.78 \mathrm{ab} \pm 0.01$ & 198 & $32.22 \mathrm{a} \pm 0.01$ & 122 & $32.58 b \pm 0.12$ \\
\hline $\mathrm{h}$ & 0.04 & 56 & $82.43 a \pm 0.12$ & 155 & $84.84 b \pm 0.14$ & 106 & $84.03 \mathrm{ab} \pm 0.66$ \\
\hline $\mathrm{c}$ & 0.01 & 56 & $6.70 \mathrm{ab}$ & 159 & $6.78 \mathrm{a}$ & 113 & $6.60 \mathrm{~b}$ \\
\hline
\end{tabular}

${ }^{1}$ LIVER - liver weight; TBSW - total boston shoulder weight; BSW - skinless and fatless boston shoulder weight; SLW - sirloin weight; A - redness; B - yellowness;

$\mathrm{CL}$ - cooking loss; $\mathrm{h}-$ hue angle; $\mathrm{c}-$ chroma.

2 Significant differences between genotypes by F-test.

${ }^{3}$ Means followed by different letters in the same line were different $(\mathrm{P}<0.05)$ by t-test.

Table 3 - Trait means obtained for the IGF-I genotypes within each sex in $\mathrm{F}_{2}$ animals

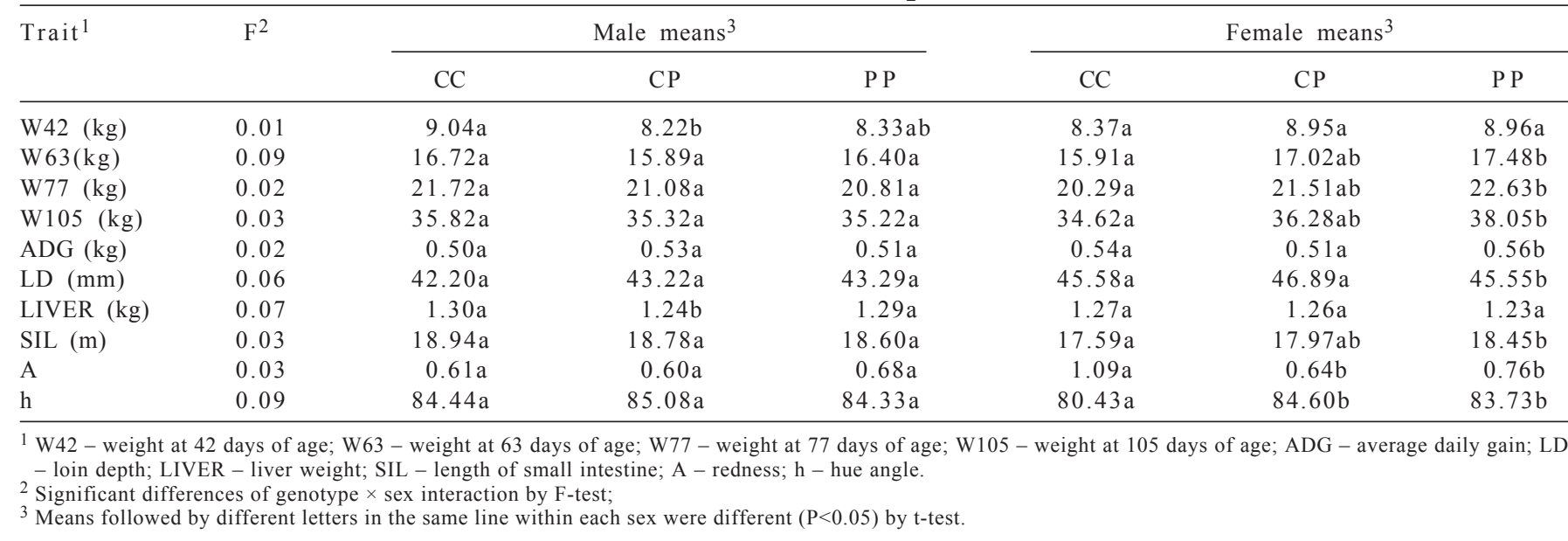


Regarding the hue angle of the pork, which in the present study showed lower means in males, no correlation with $\mathrm{pH}(\mathrm{P}>0.05)$ was observed; however, a correlation with intramuscular fat $(\mathrm{P}<0.05)$ was observed (Benevenuto Junior, 2001). An amount of lipid molecules changes the hue angle as well as the meat color saturation. With respect to redness (A), which presented higher means in females with the CC genotype, it should be noted that the higher is the redness value (A), the redder the meat will be. Despite the correlation between meat color and intramuscular fat content, no effect of the genotypes on this trait was observed in the present study for the marker analyzed.

The present results are important as they suggest a different selection of animals for each genotype within each sex. In the Duroc breed, Suzuki et al. (2004) measured the serum IGF-I concentration in males and females from different ages and observed that the concentration of this hormone increases proportionally with the animal age, but this increase is higher in males than in females. Taking these results into account, analysis of the performance of traits studied here showed that, in addition to the fact that IGF-I is positively associated with animal performance, the effect of the PP genotype on most weight parameters and average daily gain is higher in females (Table 3). Unfortunately, in the present study, no analysis of the seric IGF-I was performed.

Significant additive effects $(\mathrm{P}<0.05)$ were observed for traits TBSW, B, and c (Table 4). In addition, all traits except SLW and $B$ were found to be significant $(P<0.10)$ for dominance effect (Table 4).

The genotype of an individual is the result of intra locus interaction between its alleles, but the gene action may change within the same genotype. Therefore, it is important to test the effect of the interacting alleles within each

Table 4 - Means, and additive (A) and dominance (D) effects obtained for the IGF-I genotypes

\begin{tabular}{|c|c|c|c|c|c|}
\hline Trait $^{1}$ & $\mathrm{Mean}^{2} \mathrm{CC}$ & Mean $^{2}$ CP & Mean $^{2}$ PP & A & D \\
\hline LIVER (Kg) & $1.28(69)$ & $1.25(188)$ & $1.26(121)$ & -0.007 & $-0.04 *$ \\
\hline TBSW (Kg) & $2.25(69)$ & $2.34(190)$ & $2.35(123)$ & $0.05 * *$ & $0.08 *$ \\
\hline BSW (kg) & $1.59(68)$ & $1.69(189)$ & 1.69 (123) & 0.02 & $-0.1^{*}$ \\
\hline SLW (kg) & $0.22(68)$ & 0.22 (174) & $0.21 \quad(121)$ & -0.002 & 0.01 \\
\hline A & $0.85(61)$ & $0.62(180)$ & $0.72(108)$ & -0.04 & $-0.33 *$ \\
\hline B & $6.56(61)$ & $6.69(180)$ & $6.53(112)$ & $-0.13 * *$ & 0.29 \\
\hline CL $(\%)$ & $32.78(66)$ & 32.22 (198) & 32.58 (122) & -0.22 & $-0.92 *$ \\
\hline $\mathrm{h}$ & $82.43 \quad(56)$ & $84.84(155)$ & $84.03(106)$ & 0.03 & $3.22 *$ \\
\hline $\mathrm{c}$ & $6.70(56)$ & $6.78(159)$ & $6.60(113)$ & $-0.12 * *$ & $0.26 *$ \\
\hline
\end{tabular}

${ }^{1}$ LIVER - Liver weight; TBSW - total boston shoulder weight; BSW - skinless and fatless boston shoulder weight; SLW - sirloin weight; A - redness; B - yellowness; $\mathrm{CL}$ - cooking loss; $\mathrm{h}$ - hue angle; $\mathrm{c}$ - chroma.

2 Number of animals genotyped for each genotype is given in parentheses.

*ANOVA - significant by F-test $(\mathrm{P}<0.10)$; **significant by F-test $(\mathrm{P}<0.05)$.

genotype in order to help with the adequate selection of given genotypes for certain traits. The lack of significance for some additive and dominance effects (Table 4) might be the result of the different number of animals analyzed per genotype, for the CC genotype, the number of animals analyzed for each trait ranged from 56 to a maximum of 69 , while for PP and CP genotypes, there were respectively twice or three times more animals. With an increased number of animals, especially for the CC genotype, it could be possible to better describe additive and dominance effects.

\section{Conclusions}

The association and heterozygosity observed for the IGF-I microsatellite marker in the present population show that this marker can be used in QTL detection. Moreover, the results here presented are in accordance with literature data about QTL profile on SSC5, despite the fact that the present work describes single marker analysis. At this time, the F2 population is being genotyped for other microsatellite loci on SSC5 to confirm the existence of QTL at this genomic region.

\section{Literature Cited}

BAND, G.O.; GUIMARÃES, S.E.F.; LOPES, P.S. et al. Relationship between the Porcine Stress Syndrome gene and pork quality trait in F2 pigs resulting from divergent crosses. Genetics and Molecular Biology, v.28, n.1, p.88-91, 2005a.

BAND, G.O.; GUIMARÃES, S.E.F.; LOPES, P.S. et al. Relationship between the Porcine Stress Syndrome gene and carcass and performance trait in F2 pigs resulting from divergent crosses. Genetics and Molecular Biology, v.28, n.1, p.92-96, 2005b. 
BENEVENUTO JR., A.A. Avaliação de rendimento de carcaça e de qualidade da carne de suínos comerciais, de raça nativa e cruzados. 2001. $93 \mathrm{f}$. Dissertação (Mestrado em Ciência e Tecnologia de Alimentos) - Universidade Federal de Viçosa, Viçosa, MG, 2001

CARMO, F.M.; GUIMARÃES, S.E.F.; LOPES, P.S. et al. Association of MYF5 gene allelic variants with production traits in pigs. Genetics and Molecular Biology, v.28, n.3, p.363-369, 2005.

CASAS-CARRILlO, E.; PRILL-ADAMS, A.; PRICE, S.G. et al. Mapping genomic regions associated with growth rate in pigs. Journal of Animal Science, v.75, n.8, p.2047-2053, 1997.

DE KONING, D.G.; RATTINK, A.P.; HARLIZIUS, B. et al. Detection and characterization of quantitative trait loci for growth and reproduction traits in pigs. Livestock Production Science, v.72 n.3, p.185-198, 2001.

FARIA, D.A.; GUIMARÃES, S.E.F.; LOPES, P.S. et al. Association between G316A growth hormone polymorphism and economic traits in pigs. Genetics and Molecular Biology, v.29, n.4, p.634-640, 2006.

HORVAT, S.; MEDRANO, J.F. Interval mapping of high growth (hg), a major locus that increases weight gain in mice. Genetics, v.139, n.4, p.1737-1748, 1995.

LEE, S.S.; CHEN, Y.; MORAN, C. et al. Linkage and QTL mapping for Sus scrofa chromosome 5. Journal of Animal Breeding and Genetics, v.120, n.1, p.38-44, 2003.

MALEK, M.; DEKKERS, J.C.M.; LEE, H.K. et al. A molecular genome scan analysis to identify chromosomal regions influencing economic traits in the pig. I. Growth and body composition. Mammalian Genome, v.12, n.8, p.630-636, 2001a.

MALEK, M.; DEKKERS, J.C.M.; LEE, H.K. et al. A molecular genome scan analysis to identify chromosomal regions influencing economic traits in the pig. II. Meat and muscle composition. Mammalian Genome, v.12, n.8, p.637-645, $2001 \mathrm{~b}$.

MARSHALL, T.C.; SLATE, J.; KRUK, L. et al. Statistica Confidence for likelihood-based paternity inference in natural populations. Molecular Ecology, v.7, p.639-655, 1998.

PEIXOTO, J.O.; GUIMARÃES, S.E.F.; LOPES, P.S. et al. Associations of Leptin gene polymorphisms with production traits in pig. Journal of Animal Breeding and Genetics, v.123, p.1-6, 2006.

PURSEL, G.V.; MITCHELL, A.D.; WELLS, K.D. et al. Alteration of carcass composition in swine with an IGF-I transgene. In: CONFERENCE OF PLANT \& ANIMAL GENOME, 8., 2000 , San Diego. Proceedings... San Diego: 2000. (CD-ROM).

STATISTICAL ANALYSIS SYSTEM - SAS. User's guide. Cary: Statistical Analysis System, 1998. (CD-ROM).

SUZUKI, K.; NAKAGAWA, M.; KADOWAKI, H. et al. Genetic correlation between serum insulin-like growth factor-I concentration and performance and meat quality traits in Duroc pigs. Journal of Animal Science, v.82, n.4, p.994-999, 2004

TE PAS, M.F.W.; GERRITSEN, C.L.; VISSCHER, A.H. et al. Relationships between performance traits and the expression of growth hormone, insuline-like growth factor-I, and insulin in pigs selected for growth or leanness. Journal of Animal Breeding and Genetics, v.120, n.5, p.346-357, 2003.

US Pig Gene Mapping Coordination Program. Disponível em $<$ www.animalgenome.org/pigs> Acesso em: 15/11/2008.

WELLER, P.A.; DICKSON, M.C.; HUSKISSON, N.S. The porcine insulin-like growth factor-I gene: characterization and expression of alternate transcription sites. Molecular Endocrinology, v.11, n.2, p.201-211, 1993.

YU, T.P.; TUGGLE, C.K.; SCHMITZ C.B. et al. Association of PIT1 polymorphism with growth and carcass traits in pigs. Journal of Animal Science, v.73, n.5, p.1282-1288, 1995. 